\title{
O DRAMA DO TEATRO DE JOSÉ RÉGIO
}

Francisco Maciel Silveira

Universidade de São Paulo

\begin{abstract}
Atacar alguém o meu teatro por ser dialético, ou poético, ou espetacular, ou místico, ou metafísico, ou psicológico, ou realista, ou o que quer que seja - quando, precisamente, não pode ele deixar de ser tal em razão da própria personalidade do seu autor - parece-me coisa sem alcance nem sentido, sem inteligência nem fecundidade. (José Régio)
\end{abstract}

$\mathrm{J}$ osé Régio considerava sua dramaturgia "a parte mais original e, conseqüentemente, mais incompreendida” de sua obra. Em sua óptica, portanto, a incompreensão, seja por parte da crítica, seja por parte do público, decorria da originalidade de suas concepções.

Em que consistia essa originalidade? Em grande parte, na presença numinosa de uma temática metapsíquica e metapsicológica, como a que presenciamos em textos como Jacob e o Anjo, Benilde ou a Virgem Mãe, El-Rei Sebastião, A salvação do mundo. Uma temática que, caudatária de seu misticismo e religiosidade heterodoxos, implicava, para sua aceitação, a comparticipação da Fé de uma platéia cujo gosto teatral propendia para espetáculos mais digestivos, diferentes, portanto, daqueles que José Régio lhes oferecia. Afinal, como diz o Espectador de $O$ meu caso (1957), vai-se ao teatro para uma distraçãozinha descompromissada e não para agoniar-se à luz (e trevas) de conflitos em que, - para usarmos a síntese de Jorge de Sena, em Contos exemplares, - "um espiritualismo atraído e repelido pela simbologia 
cristã e católica" metaforiza "uma sensual dialética da carne-espírito" (SENA, 1988, p.322).

Por outro lado, a originalidade presencista de Régio vinha do mais fundo de sua individualidade e autenticidade, perigando exaurir-se, intransitivamente, em si mesma. Isto é, forcejava por alcançar a Universalidade, mas dizia respeito tão somente ao seu $\mathrm{Eu}$ de homem profundamente religioso, dilacerado por uma especulação metapsicológica sobre a estrutura e função do Espírito, bem como sobre as relações entre o Espírito e a Realidade.

Um terceiro aspecto da originalidade regiana reside em sua concepção espetacular de teatro. E aqui talvez assista o grande paradoxo da dramaturgia de José Régio - sua concepção espetacular de teatro (a que deveria dar viabilidade cênica às intenções do Autor) acaba sendo responsável pela inviabilidade cênica ou irrepresentabilidade da maioria de suas peças.

Quer-me parecer que esta concepção espetacular que sempre o preocupou seria a maneira de teatralizar aquela temática metapsíquica e metapsicológica que Régio sabia ser, em essência e implicações filosóficoreligiosas, literária e doutrinal. Que o diga a grandiloqüência poético-barroca das falas de suas personagens, redundantemente didáticas na exposição de sua mensagem.

Para mal dos pecados dramatúrgicos de José Régio, nossa relação com a Realidade fenomênica é à São Tomé. Herdeiros de uma epistemologia cientista, temos de ver para crer. Temos de provar para crer. Não é isso o que sugere Régio em Benilde ou a Virgem-Mãe, quando contrapõe o Padre e o Doutor diante do mistério daquela Anunciação, daquele Ave, Benilde, cheia de Graça? Ou seja, o contraponto entre a Fé e sua crença no sobrenatural versus o cepticismo da Ciência posta diante daquela mariana concepção sem pecado. Nossa dúvida, (em que partido acreditar: na doutoral Ciência ou na sobrenatural Religião?) personifica-a Genoveva, a velha criada da casa, indecisa entre a inocência de Benilde e a nocência de um sonambúlico ato dos instintos, ainda mais quando sua vicária filha descende, naturalisticamente, de uma mãe histérica dada a raptos místicos prenhes de carnalidade.

Como carnalizar as experiências, raptos e/ou intuições ascético-místicas de sua temática metapsíquica e metapsicológica, se não através da corporificação, do Verbo caro factum est, ínsitos ao teatro? 
Neste aspecto, a dramaturgia regiana lembra-me os exempla-moralidade tão em voga na parênese barroca: casos maravilhosos, miraculosos, sobrenaturais que, presentificados ante nossos olhos incrédulos e ouvidos moucos, realizam o movimento descendente do Céu que baixa à Terra no Espírito, - a corporificar-se em entes como o Anjo de Jacob e o Sapateiro Santo de El-Rei Sebastião, a manifestar-se na concepção sem pecado de Benilde, a expressarse, paradoxalmente, no evangelho tácito de $A$ salvação do mundo.

A concepção espetacular que Régio tem do teatro, envolvendo todos os signos (do ator ao cenário, da música ao adereço e figurino, da marcação à coreografia) que lhe são inerentes, está a serviço da mensagem e de sua corporificação.

Tinha Régio consciência de suas “novidades espetaculares”. Guiava-o a convicção de que "só a experiência do palco demonstrará a eficiência ou a deficiência da linguagem duma obra teatral, linguagem que se não pode reduzir a literariamente superior, pois o há-de ser também espetacularmente”. ${ }^{1}$

E foi exatamente esta prova do palco que sempre o preocupou. Num primeiro momento, com o natural desejo de todo dramaturgo - o de ver suas peças encenadas. Quando lhe surgia a oportunidade de vê-las encenadas (Jacob e o Anjo e Benilde), com a preocupação de assistir aos ensaios, sugerir atores adequados a determinadas personagens, lembrar a importância da música ou do cenário, gizar a indumentária mais conveniente ou significativa.

Toda esta preocupação testemunha-se na correspondência que, por dez anos (ago./43 a fev./53), travou com a Cia de Amélia Rey Colaço-Robles Monteiro (concessionária à época do Teatro Nacional D. Maria II e responsável pela encenação de Benilde, em 25/nov/47). Nesta correspondência (SANTOS, 1989, p. 63-80) vemos gradativamente crescer sua dúvida quanto à representabilidade de suas concepções espetaculares.

\footnotetext{
"Porém outra modalidade de teatro existiu, existe, existirá, em que a Palavra está longe de tudo dizer. Com ela se conjugam a música e a dança, os efeitos de luz e a pintura, a arquitectura cenográfica, a pura declamação e outros recursos não literários - na expressão de personalidades que a mera expressão literária parece não satisfazer.” (“Nota preambular”, El-Rei Sebastião, Coimbra, Atlântida, 1949, p. XIII.)
} 
Um rápido passar d'olhos nas aludidas cartas vai pouco a pouco depondo-o da cátedra de dramaturgo consciente de suas realizações e intransigente quanto a qualquer corte de falas e cenas, em direção a uma transigência da qual, inclusive, vai arrepender-se.

De 1943 a 1947, as missivas, dirigidas ora a Amélia Rey Cola $\div$ o, ora a Robles Monteiro, tratam do interesse (e misterioso desinteresse) daquela Companhia por Jacob e o Anjo ${ }^{2}$ e das tratativas para a bem sucedida realização em cena de Benilde ou a Virgem-Mãe - encenação cuja qualidade satisfizera Régio a ponto de não regatear elogios à competência profissional de uma Cia de que ficará sincero admirador e junto à qual tentará outros cometimentos frustrados: El-Rei D. Sebastião, em 1949, e A salvação do mundo, em 1951.

Nas cartas do período acima referido (1943-1947), José Régio ostenta sua arraigada defesa do "teatro do autor". Ao tratar da frustrada encenação de Jacob e o Anjo (cartas de 27/ago./43; 19/set./43; 14/mar./44; 25/nov./44) faz exigências de "um autor impertinente": preocupa-se com os signos teatrais que devem ser postos a serviço da parte espetacular; exige obediência ao pensamento do Autor; preocupa-o o ator que irá representar o Anjo, chegando a sugerir que haja dois, um para a parte coreográfica, outro para a parte dramática, propriamente dita; deseja receber apontamentos acerca do figurino, já que dá muita importância à indumentária do Bobo-Anjo, trajo que lhe não parece fácil de conceber ou realizar; ante a observação de Amélia Rey Colaço de que Jacob e o Anjo "não poderá nunca ser representado sem uns ligeiros cortes indispensáveis para que a sua realização cênica resulte”, afirma que não cortará cena alguma, nem nada de essencial à peça, embora não faça questão "de aligeirar ou encurtar certas falas". ${ }^{3}$

O ano de 1947 assiste às tratativas de Régio para a encenação de Benilde ou a virgem-mãe, ainda a cargo da Cia Rey Colaço-Robles Monteiro. São ao todo quatro cartas (06/10/1947; 13/10/47; 1/12/47 e 4/12/47), das quais nos

2 Rumores atribuíam a Amélia Rey Colaço considerar a peça "irrepresentável”; daí a desistência da Cia.

3 No que parece ter sido sua última carta a Amélia Rey Colaço, datada de 1/fev./1953, José Régio pede a devolução de um "arranjo teatral” que fizera em Jacob e o Anjo, arranjo que resultara na amputação de uma personagem e do qual se arrependera. 


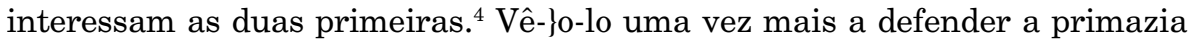
do autor e do texto em sua concepção espetacular de teatro. Nas duas cartas referidas, insiste na maior dificuldade que vê: o desempenho dos papéis de Benilde e Eduardo, julgando depender da atuação dos atores "o bom ou mau êxito da realização cênica da peça”. Ademais, antepõe duas condições: 1) recusaria a autorização para a encenação da peça no caso de, tendo assistido a alguns ensaios, julgasse que representação não atingia o nível necessário a um relativo êxito; 2) não cortaria uma palavra dos diálogos; só no caso de "espontaneamente" julgar conveniente, faria qualquer alteração.

Seja porque a encenação de Benilde suscitou interesse em apenas parte do público, seja porque a opinião da crítica se dividiu, nota-se que, pouco a pouco, José Régio começa a duvidar da viabilidade cênica de sua concepção espetacular.

Em 19/10/49 oferece ao casal Amélia Colaço/ Robles-Monteiro El-Rei Sebastião. Em 20/10/1951 proporá à mesma Cia $A$ salvação do mundo. Já não se observam em ambos os casos aquelas exigências do "autor impertinente". Sua concepção espetacular traz-lhe dificuldades e dúvidas de vária ordem. "É o fado de seu teatro", afirma. Ou seja, idear uma espetacularidade teatral que, na prova do palco, resultava irrepresentável.

É o caso de El-Rei Sebastião. Sabe-a Régio "com novidades espetaculares que nenhuma outra peça (sua ou de qualquer autor contemporâneo) apresenta". Tratava-se, contudo, de um "poema espetacular em três atos". Natural que venha a perceber que, sendo toda a ação interior, a ação exterior resulte débil, para não dizermos inexistente, sufocada pela retórica poética da maioria dos diálogos. A exemplo do que ocorre com Jacob, o conflito de D. Sebastião já está resolvido, desde o início, com a vitória do Espírito sobre a Carne. Aí residiriam as "fraquezas de certo ponto de vista teatral” que detecta na peça, sem, todavia, especificá-las?

Nas cartas endereçadas a Amélia Rey e Robles Monteiro, ao seu crivo crítico não escapa também $A$ salvação do mundo. Trata-se, em sua óptica, de uma tragicomédia chocha, aborrecida (os adjetivos são de José Régio),

4 As cartas de 1 e 4 de dezembro de 1947 traduzem sua satisfação pelo espetáculo, pelo desempenho dos atores em Benilde ou a Virgem-Mãe, que subira ao palco em 25/11/47. 
cuja única salvação estava na figura da Rainha-Mãe, donde preocuparemno, numa possível encenação, a indumentária e interpretação adequadas à personagem.

As encenações de Jacob e o Anjo e de $A$ salvação do mundo, a primeira pela Cia do Teatro Popular em 1968 e a segunda pela Cia do Teatro Municipal em novembro de 1971, podem ser lembradas como representativas do desafio com que se defrontava sua concepção teatral - o desafio da viabilidade cênica de sua ideação espetacular na prova do palco.

Não vou entrar no mérito das críticas, pois não vi as representações. As críticas, vou tratá-las como emblemáticas de um conflito que estava no teatro de José Régio. Um conflito que não residia no âmago das peças estava fora delas, na coxia de sua carpintaria dramatúrgica: o conflito entre a consciência que Régio tinha do métier teatral e sua fatura, sua realização, sua posta em cena.

Jacob e o Anjo, encenada pela Cia de Teatro Popular em 1968, recebe dura crítica de Carlos Porto, que põe em causa exatamente sua viabilidade cênica. Diz o articulista responsável pela crítica:

Quando a leitura de uma peça nos entusiasma e a sua montagem em palco nos desilude, podemos atribuí-lo não apenas às deficiências do espetáculo como a deficiências do próprio texto que aquelas vieram pôr a nu e que uma má leitura não nos deixara perceber. Jacob e o Anjo dizem-no os mais responsáveis de nossos críticos é uma obra-prima do teatro português. Após vermos a decisiva prova do palco, pedimos licença para discordar. Apesar de em alguns aspectos ser estimável, trata-se quanto a nós de uma peça falhada.

Após assinalar deficiências no texto (ausência de conflito na dialética Carne/Espírito, homem/Deus; o conflito secundário na trama palaciana aparece sem interesse, encarnado por personagens demasiado esquemáticas, exceção feita à Rainha; a linguagem, a par de coisas muito belas, enferma pelo convencionalismo de clichês poéticos dessorados), lamenta o crítico não tenham o encenador, nem o cenógrafo, nem o figurinista, nem a iluminação tampouco a sonoplastia ou os atores concorrido para salvar um pouco o espetáculo: “A C.T.P. não tinha condições para pôr esta peça em cena. O 
principal erro de Orlando Vitorino (o encenador), a nosso ver, foi não se ter apercebido de que não é possível fazer omeletas sem ovos."

Outra mal sucedida prova no palco teria sido A salvação do mundo, encenada pela Cia do Teatro Municipal, em 1971. Di-lo ainda Carlos Porto (1973, p. 231-234), sublinhando - note-se - o problema da desejada espetacularidade, ao assinalar "a falta de teatralidade de uma linguagem que não permite que ao menos o texto se erga acima da mediocridade do resto" (p. 233).

Dir-se-á que levantar estas duas críticas foi um mau serviço prestado à memória de José Régio nesta ocasião. Contudo, na exposição, fica patente $o$ drama do teatro de José Régio, como anunciava o título desta intervenção. Um drama que, nas elucubrações teatrais de José Régio, se punha, de fato, fora do palco: o conflito entre a teoria de um autor plenamente consciente do que seja teatro e a prática cênica de suas concepções espetaculares.

E como disse a epígrafe desta comunicação: não se podem fazer restrições às presencistas sinceridade e autenticidade e originalidade de Régio, que dizia que "a todo artista pertence o direito de realizar o que quere e pode" O conflito do teatro de Régio, um conflito vivido fora do tablado, esteve exatamente entre este querer e este poder. Quis concepções dramáticas espetaculares que, na prática do palco, não pôde realizar.

Ao cabo, um teatro que, traindo sua concepção espetacular, sobreviveu como gênero literário. Para desgosto de sua lúcida consciência crítica. Afinal, sabia-o e declarava-o, alto e bom som, - conforme se lê na "Nota Preambular" de seu poema espetacular El Rei-Sebastião - que "teatro está longe de ser só a sua literatura, por isso mesmo que sempre há-de ser espetáculo.”

Não obstante a profissão de fé, uma obra teatral que, contrariando toda a sua ambição dramatúrgica, resultou literária. Mística, metafísica, psicológica, poética, mas literária.

O teatro de Régio não poderia ser de outro modo. Não poderia deixar de ser tal como o foi, em razão da personalidade do autor. Absolutamente coerente, pois, com a afirmação que lhe transcrevi como epígrafe destas considerações: a expressão autêntica e sincera de sua personalidade intrinsecamente poética, religiosa, doutrinal, literária - mas não teatralmente espetacular. 


\section{BIBLIOGRAFIA}

PORTO, Carlos. Em busca do teatro perdido II. Lisboa: Ed. Plátano, 1973.

SANTOS. Vítor Pavão dos. Vinte e uma cartas colhidas em A Companhia Rey

Colaço-Robles Monteiro - Correspondência 1921-1974. Lisboa: Secretaria do Estado da Cultura, 1989.

SENA, Jorge de. Do teatro em Portugal. Lisboa: Edições 70, 1988. 